\title{
Influence of Termovet and Prodactive Acid SE preparations on blood parameters of broiler chickens
}

\author{
Svetlana Alexandrova, and Alexey Bakharev* \\ Research Institute of Agriculture NW branch of Tyumen Scientific Center SB RAS, Russia
}

\begin{abstract}
The studies' results of blood and biochemical parameters of its serum in broiler chickens exposed to high ambient temperatures are presented. Heat stress causes physiological changes in the poultry body, which negatively affects its health, feed intake and digestibility, productivity and product quality. To alleviate the poultry condition, a water-soluble powder of the Termovet preparation of acetylsalicylic acid $(750 \mathrm{mg} / 1 \mathrm{~g})$ was used for oral administration. As well as Prodactive Acid $\mathrm{SE}$ - a mixture of organic acids. The chicks' growing period was 34 days. The main period of the experiment began when the poultry reached an average live weight of $1680 \mathrm{~g}$ at the age of 4 weeks. Upon reaching an average live weight of $2030 \mathrm{~g}$ within 6 days before withdrawal from the experiment, the room was heated to $35^{\circ} \mathrm{C}$ from 8 am to $6 \mathrm{pm}$. At this time, Termovet preparation was poured into the drinkers in the following doses: experimental group I - $100 \mathrm{mg} / \mathrm{kg}$ of live weight, experimental group II $150 \mathrm{mg} / \mathrm{kg}$. Both experimental groups were given Prodactive Acid SE last thing at night in a dose that provided water $\mathrm{pH}$ of 4 . Research results have shown that the use of these preparations had a positive effect on the hematological and biochemical parameters of chickens when exposed to high temperatures.
\end{abstract}

\section{Introduction}

Heat stress causes physiological changes in the poultry body, which negatively affects its health, feed intake and digestibility, productivity and product quality. As a result, such production indicators as average daily live weight gain, feed conversion, and safety are significantly reduced. This leads to significant financial losses and a decrease in the profitability of poultry products' production.

Acetylsalicylic acid prevents thrombogenesis and has anti-inflammatory, antipyretic effects. It is an active ingredient in the Termovet preparation water-soluble powder $[1,2$, $3]$.

*Corresponding author: salers@mail.ru 


\section{Materials and methods}

The studies were carried out in laboratory conditions of the Research Institute of Agriculture of the Northern Trans-Urals, a branch of the Tyumen Scientific Center of the SB RAS. The object of the study was broiler chickens of the Arbor Acres + cross. The experimental chickens were divided into three groups according to the principle of balanced analog groups with 40 heads in each group. The experiment lasted for 34 days. The main period of the experiment began when the poultry reached an average live weight of $1680 \mathrm{~g}$ at the age of 4 weeks. Upon reaching an average live weight of $2030 \mathrm{~g}$ within 6 days before withdrawal from the experiment, the room was heated to $35^{\circ} \mathrm{C}$ from 8 am to $6 \mathrm{pm}$. At this time, Termovet preparation was poured into the drinkers in the following doses: experimental group I - $100 \mathrm{mg} / \mathrm{kg}$ of live weight, experimental group II - $150 \mathrm{mg} / \mathrm{kg}$, control group - no preparation used. Both experimental groups were given Prodactive Acid $\mathrm{SE}$ last thing at night in a dose that ensures water $\mathrm{pH}$ of 4 , which amounted to $1 \mathrm{ml} /$ liter in this case (depending on the composition and $\mathrm{pH}$ of the water used).

All conditions of cage keeping, microclimate parameters were identical in all studied groups. The feed was recorded daily $[4,5,6]$.

Termovet preparation is a water-soluble powder of acetylsalicylic acid $(750 \mathrm{mg} / 1 \mathrm{~g})$ for oral administration. Producer - "Divasa-Farmavic S.A." (Spain). Prodactive Acid SE contains the following acids: formic acid not less than $61 \%$, lactic acid not less than $8 \%$, propionic acid not less than 5\%, citric acid not less than 3\% and acetic acid not less than $2 \%$. Developed by VIK - Animal Health LLC (Russia). The physiological state of poultry was accessed by monitoring the blood parameters of the morphological and biochemical composition during the main period of the experiment. The material for the study was blood taken from four typical chickens of each group by decapitation at 28 days and 34 days of age. The following was determined in the test material: blood cells number, leukocyte formula, biochemical parameters and minerals. The studies were carried out in the hemoanalytical laboratory of the State Educational Institution of Higher Professional Education TyumSMA, Roszdrav.

All examinations were biometrically processed with significant difference calculation.

\section{Results and discussion}

In the body, blood maintains an internal connection between individual organs and tissues providing the required nutrients $[7,8]$.

Any changes in the body will directly affect the blood composition, which serves as an indicator of the body's reactivity and characterizes its overall resistance $[9,10,11]$.

In this research work, the biochemical composition of blood serum in experimental groups of broiler chickens at the beginning and end of the experimental period was studied (table 1, 2).

Table 1. Biochemical blood serum composition of broiler chickens.

\begin{tabular}{|l|c|c|c|c|}
\hline \multirow{2}{*}{ Indicator } & \multirow{2}{*}{$\begin{array}{c}\text { Measurement } \\
\text { units }\end{array}$} & \multicolumn{3}{|c|}{ Group } \\
\cline { 3 - 5 } & \multicolumn{4}{|c|}{ at the beginning of the experimental record period } \\
\hline Glucose & $\mathrm{mmol} / 1$ & $14.30 \pm 0.58$ & $14.53 \pm 0.90$ & $13.15 \pm 0.40$ \\
\hline $\begin{array}{l}\text { Alanine } \\
\text { aminotransferase }\end{array}$ & unit/1 & $6.47 \pm 1.31$ & $8.47 \pm 3.57$ & $5.73 \pm 1.73$ \\
\hline $\begin{array}{l}\text { Aspartate } \\
\text { aminotransferase }\end{array}$ & unit/1 & $276.47 \pm 67.13$ & $294.77 \pm 42.25$ & $382.73 \pm 80.35$ \\
\hline Total protein & $\mathrm{g} \backslash 1$ & $32.23 \pm 1.76$ & $28.30 \pm 1.17$ & $30.67 \pm 2.09$ \\
\hline Albumin & $\mathrm{g} \backslash 1$ & $14.03 \pm 0.78$ & $11.70 \pm 0.67$ & $12.53 \pm 0.40$ \\
\hline
\end{tabular}




\begin{tabular}{|l|c|c|c|c|}
\hline Urea & $\mathrm{mmol} / 1$ & $0.53 \pm 0.12$ & $0.68 \pm 0.00$ & $0.70 \pm 0.16$ \\
\hline Creatinine & $\mu \mathrm{mol} / \mathrm{l}$ & $24.00 \pm 0.71$ & $21.00 \pm 2.83$ & $22.67 \pm 1.08$ \\
\hline Uric acid & $\mu \mathrm{mol} / 1$ & $354.33 \pm 46.00$ & $240.67 \pm 11.97$ & $288.67 \pm 85.66$ \\
\hline Calcium & $\mathrm{mmol} / 1$ & $2.71 \pm 0.01$ & $2.74 \pm 0.01$ & $2.60 \pm 0.03$ \\
\hline Phosphorus & $\mathrm{mmol} / 1$ & $2.13 \pm 0.06$ & $2.15 \pm 0.09$ & $2.01 \pm 0.06$ \\
\hline Potassium & $\mathrm{mmol} / 1$ & $4.58 \pm 0.51$ & $4.62 \pm 0.19$ & $4.93 \pm 0.20$ \\
\hline Sodium & $\mathrm{mmol} / 1$ & $148.23 \pm 0.45$ & $149.47 \pm 0.66$ & $148.57 \pm 1.50$ \\
\hline Calcium & $\mathrm{mmol} / 1$ & $1.46 \pm 0.01$ & $1.47 \pm 0.01$ & $1.45 \pm 0.01$ \\
\hline \multicolumn{4}{|c|}{ at the end of the experimental record period } \\
\hline Glucose & $\mathrm{mmol} / 1$ & $14.46 \pm 0.69$ & $14.53 \pm 0.20$ & $15.03 \pm 0.52$ \\
\hline $\begin{array}{l}\text { Alanine } \\
\text { aminotransferase }\end{array}$ & $\mathrm{unit} / 1$ & $3.45 \pm 0.62$ & $5.05 \pm 1.37$ & $4.48 \pm 1.62$ \\
\hline $\begin{array}{l}\text { Aspartate } \\
\text { aminotransferase }\end{array}$ & $\mathrm{unit} / 1$ & $401.95 \pm 73.56$ & $364.95 \pm 50.00$ & $352.65 \pm 97.90$ \\
\hline Total protein & $\mathrm{g} / \mathrm{l}$ & $36.08 \pm 2.42$ & $35.35 \pm 1.03$ & $30.25 \pm 0.68$ \\
\hline Albumin & $\mathrm{gll}$ & $14.75 \pm 0.81$ & $14.93 \pm 0.56$ & $12.80 \pm 0.41$ \\
\hline Urea & $\mathrm{mmol} / 1$ & $0.43 \pm 0.05$ & $0.44 \pm 0.07$ & $0.57 \pm 0.11$ \\
\hline Creatinine & $\mu \mathrm{mol} / 1$ & $16.25 \pm 1.59$ & $17.50 \pm 1.80$ & $16.75 \pm 1.09$ \\
\hline Uric acid & $\mu \mathrm{mol} / 1$ & $219.50 \pm 52.70$ & $186.25 \pm 64.83$ & $137.00 \pm 43.90$ \\
\hline Calcium & $\mathrm{mmol} / 1$ & $2.57 \pm 0.05$ & $2.55 \pm 0.02$ & $2.61 \pm 0.06$ \\
\hline Phosphorus & $\mathrm{mmol} / 1$ & $1.79 \pm 0.07$ & $1.86 \pm 0.14$ & $1.98 \pm 0.10$ \\
\hline Potassium & $\mathrm{mmol} / 1$ & $4.42 \pm 0.03$ & $4.66 \pm 0.34$ & $4.72 \pm 0.31$ \\
\hline Sodium & $\mathrm{mmol} / 1$ & $152.20 \pm 1.52$ & $154.08 \pm 1.17$ & $152.90 \pm 1.40$ \\
\hline Calcium & $\mathrm{mmol} / 1$ & $1.34 \pm 0.02$ & $1.37 \pm 0.02$ & $5.62 \pm 0.02$ \\
\hline
\end{tabular}

At the beginning of the experimental period, blood and serum indices were within the normal range both between groups and relative to the reference range in all groups of poultry.

At the end of the experimental period, the chickens of the control group showed more uric acid than the chickens of the I experimental group by $33.25 \mu \mathrm{mol} / 1$. But it should be noted that this indicator was within the physiological norm in chickens of all studied groups.

The level of aspartate aminotransferase (AST) can be used to judge liver function. Normal values are up to $330 \mathrm{U} / \mathrm{l}$ in most poultry species. This indicator in the poultry of the control group was $401.95 \mathrm{U} / 1$, in the I experimental group - $364.95 \mathrm{U} / 1$, which was higher by $37 \mathrm{U} / 1$. Both indicators were above normal, which can be explained by the negative impact of the stress factor of elevated temperature. It should be noted that AST was normal in both groups before exposure to the stress factor. The norm for this indicator is up to 330 $\mathrm{U} / 1$.

More uric acid was also noted in the blood serum of the control group chickens by 82.5 $\mathrm{mmol} / \mathrm{l}$ in relation to the analogs of the II experimental group. In this case, the indicator of uric acid was within the physiological norm in chickens of all groups.

The serum aspartate aminotransferase index in chickens of the control group was by 49.3 U/l higher than in the II experimental group. Both indicators were above normal, which can be explained by the negative impact of the stress factor of elevated temperature. No statistically significant differences were found in the data in Table 1.

The results of hematological parameters of broiler chickens' blood are presented in Table 2. 
Table 2. The study results of broiler chickens' red blood at the beginning of the experimental record period.

\begin{tabular}{|c|c|c|c|c|}
\hline \multirow{2}{*}{ Indicator } & \multirow{2}{*}{$\begin{array}{c}\text { Measurement } \\
\text { units }\end{array}$} & \multicolumn{3}{|c|}{ Group } \\
\hline & & control & I experimental & II experimental \\
\hline \multicolumn{5}{|c|}{ at the beginning of the experimental record period } \\
\hline Leukocytes & $10 * 9 / 1$ & $20.06 \pm 1.23$ & $15.70 \pm 1.82$ & $17.29 \pm 4.18$ \\
\hline Erythrocyte concentration & $10 * 12 / 1$ & $2.45 \pm 0.17$ & $2.26 \pm 0.11$ & $2.34 \pm 0.14$ \\
\hline Hemoglobin & $\mathrm{g} / \mathrm{l}$ & $111.67 \pm 2.94$ & $101.00 \pm 2.45$ & $106.00 \pm 6.01$ \\
\hline Hematocrit & $\%$ & $36.77 \pm 1.13$ & $33.80 \pm 0.90$ & $34.97 \pm 1.95$ \\
\hline $\begin{array}{l}\text { Average erythrocyte } \\
\text { volume }\end{array}$ & $\mathrm{fl}$ & $150.80 \pm 5.88$ & $149.60 \pm 3.21$ & $149.57 \pm 2.16$ \\
\hline $\begin{array}{l}\text { Average hemoglobin } \\
\text { content in a single } \\
\text { erythrocyte }\end{array}$ & $\mathrm{g} / 1$ & $45.83 \pm 1.98$ & $44.67 \pm 1.04$ & $45.47 \pm 0.20$ \\
\hline $\begin{array}{l}\text { Average hemoglobin } \\
\text { concentration in } \\
\text { erythrocyte }\end{array}$ & $\mathrm{fl}$ & $304.00 \pm 1.41$ & $299.00 \pm 2.55$ & $304.33 \pm 2.94$ \\
\hline Platelets & $10 * 9 / 1$ & $42.30 \pm 4.80$ & $44.43 \pm 1.16$ & $42.80 \pm 5.06$ \\
\hline Pseudoeosinophils & $\%$ & $44.33 \pm 3.56$ & $51.67 \pm 4.55$ & $50.67 \pm 9.34$ \\
\hline Eosinophils & $\%$ & $6.67 \pm 0.82$ & $8.67 \pm 3.27$ & $9.00 \pm 2.55$ \\
\hline Monocytes & $\%$ & $5.67 \pm 0.41$ & $4.67 \pm 2.04$ & $5.00 \pm 1.41$ \\
\hline Lymphocytes & $\%$ & $39.67 \pm 2.16$ & $28.00 \pm 6.16$ & $30.33 \pm 10.64$ \\
\hline ESR & $\mathrm{ml} / \mathrm{h}$ & $2.00 \pm 0.00$ & $2.00 \pm 0.00$ & $2.00 \pm 0.00$ \\
\hline \multicolumn{5}{|c|}{ at the end of the experimental record period } \\
\hline Leukocytes & $10 * 9 / 1$ & $15.50 \pm 1.78$ & $21.99 \pm 3.45$ & $15.69 \pm 0.93$ \\
\hline Erythrocyte concentration & $10 * 12 / 1$ & $2.59 \pm 0.08$ & $2.71 \pm 0.07$ & $2.51 \pm 0.04$ \\
\hline Hemoglobin & $\mathrm{g} / 1$ & $112.00 \pm 3.86$ & $119.00 \pm 4.14$ & $116.25 \pm 2.67$ \\
\hline Hematocrit & $\%$ & $36.85 \pm 0.96$ & $39.73 \pm 1.41$ & $37.13 \pm 0.86$ \\
\hline $\begin{array}{l}\text { Average erythrocyte } \\
\text { volume }\end{array}$ & $\mathrm{fl}$ & $142.63 \pm 4.28$ & $146.65 \pm 2.31$ & $148.20 \pm 3.52$ \\
\hline $\begin{array}{l}\text { Average hemoglobin } \\
\text { content in a single } \\
\text { erythrocyte }\end{array}$ & $\mathrm{g} / 1$ & $43.28 \pm 0.98$ & $43.95 \pm 0.53$ & $46.35 \pm 1.00$ \\
\hline $\begin{array}{l}\text { Average hemoglobin } \\
\text { concentration in } \\
\text { erythrocyte }\end{array}$ & $\mathrm{fl}$ & $304.00 \pm 8.77$ & $299.75 \pm 5.57$ & $313.50 \pm 13.80$ \\
\hline Platelets & $10 * 9 / 1$ & $9.70 \pm 1.44$ & $12.22 \pm 1.14$ & $12.52 \pm 0.94$ \\
\hline Pseudoeosinophils & $\%$ & $35.75 \pm 4.91^{*}$ & $33.00 \pm 2.05$ & $18.50 \pm 4.36$ \\
\hline Eosinophils & $\%$ & $6.50 \pm 1.20^{*}$ & $3.75 \pm 1.79$ & $3.00 \pm 0.67$ \\
\hline Monocytes & $\%$ & $50.50 \pm 4.93$ & $59.00 \pm 1.70$ & $76.50 \pm 4.41^{* *}$ \\
\hline Lymphocytes & $\%$ & $6.50 \pm 0.33$ & $4.25 \pm 1.44$ & $2.00 \pm 0.58^{* * *}$ \\
\hline ESR & $\mathrm{ml} / \mathrm{h}$ & $2.00 \pm 0.00$ & $2.00 \pm 0.00$ & $2.00 \pm 0.00$ \\
\hline
\end{tabular}

${ }^{*} \mathrm{P} \geq 0.90 ; * * \mathrm{P} \geq 0.990, * * * \mathrm{P} \geq 0.999$

The obtained results show that the number of leukocytes in the chickens' blood in the control group was lower than that of the 1 st experimental group by $6.49 \times 10^{9} / 1$ and was lower than the reference values $\left(20-40 \times 10^{9} / 1\right)$. This indicator in chickens of the I experimental group was included in the reference range and was within the physiological norm.

The number of erythrocytes in the chickens' blood of both groups was below normal (3$\left.4 \times 10^{12} / 1\right)$. It should be noted that the hemoglobin content in the subjects' blood of the I experimental group was higher by $7 \mathrm{~g} / \mathrm{l}$ in relation to the control group and was within the normal range (80-120 g/l) [12,13].

The hematocrit index in chickens of both experimental groups was at the lower limit of 
the norm. Moreover, in the chickens of the I experimental group it was higher than the minimum value $(37 \%)$ by $2.73 \%$, and in the control group - lower by $0.15 \%$. The recommended hematocrit value is $37-50 \%$.

The platelets number in the chickens' blood in the control group was inferior to the I experimental group by $2.52 \times 10^{9} / 1$, and to the II experimental group - by $2.82 \times 10^{9} / 1$.

The chickens' blood pseudoeosinophils of the experimental groups were slightly higher than the reference range (24-30\%), and in the control group they were $2.75 \%$ higher than in the I experimental group. There were also more eosinophils in the control than in the I experimental group by $2.75 \%$.

It should be noted that the number of monocytes at the beginning of the experiment was $4.7-5.7 \%$, by the end of the experiment their ratio reached $50.5-76.5 \%$, with a higher value in chickens of the II experimental group $(\mathrm{P} \geq 0.990)$. On the contrary, at the beginning of the experiment lymphocytes were at the level of $28.0-39.7 \%$, and after the use of the studied preparations their level decreased to $2.0-6.5 \%$ with a minimum value in chickens of the II experimental group $(\mathrm{P} \geq 0.999)$.

\section{Conclusions}

1. At the beginning of the experimental period, blood and serum indices were within the normal range both between groups and relative to the reference range in all groups.

2. At the end of the experimental period, the amount of uric acid in the blood serum from the control group chickens increased by $33.25 \mathrm{mmol} / \mathrm{l}$ than that in the I experimental group and by $82.5 \mathrm{mmol} / \mathrm{l}$ in the II experimental group. The level of aspartate aminotransferase in the control group chickens was $401.95 \mathrm{U} / 1$, and in the I experimental group - $364.95 \mathrm{U} / 1$, which was $37 \mathrm{U} / 1$ higher and $49.3 \mathrm{U} / 1$ than in the II experimental group. The indicators were above normal, which can be explained by the negative impact of the stress factor of elevated temperature. It should be noted that AST was normal in both groups before exposure to the stress factor.

3 . The number of leukocytes in the blood of the control group chickens was less by $6.49 \times 10^{9} / 1$ than in the first experimental group and lower than the reference values $(20-40$ $\left.\mathrm{x} 10^{9} / 1\right)$. This indicator in chickens of the I experimental group was included in the reference range and was within the physiological norm. The number of erythrocytes in the chickens' blood of both groups was below normal (3-4 x 10 $12 / 1)$. At the same time, the hemoglobin level in the blood of the I experimental group chickens was higher by $7 \mathrm{~g} / \mathrm{l}$ compared to the control group but was within the normal range.

4. The hematocrit index in chickens of both experimental groups was at the lower limit of the norm. Moreover, in the chickens of the I experimental group it was higher than the minimum value $(37 \%)$ by $2.73 \%$, and in the control group - lower by $0.15 \%$. The number of platelets in the blood of the I experimental group chickens was $2.52 \times 10^{9} / 1$ higher than that in the control group.

5. The chickens' blood pseudoeosinophils of the experimental groups were slightly higher than the reference range (24-30\%), and in the control group they were $2.75 \%$ higher than in the I experimental group. There were also more eosinophils in the control than in the I experimental group by $2.75 \%$. The content of lymphocytes in the blood of the I experimental group chickens was $8.5 \%$ higher than in the control group.

\section{References}

1. https:/vicgroup.ru/str/gk-vik-segodnya/gk-vik-segodnya/ DOI 10.1007/s10534-0180141-3 
2. S. Aleksandrova, O. Simonov, et al. BioMetals, 31(6), 975-980 (2018)

3. A.A. Bakharev, O.M. Sheveleva, K.A. Fomintsev, K.N. Grigoryev, A.G. Koshchaev, K.A. Amerkhanov, I.M. Dunin, Journal of Pharmaceutical Sciences and Research, 10(9), 2383-2390 (2018)

4. Methodology for conducting scientific and industrial research on feeding poultry, 51 (2013)

5. A.I. Ovsyannikov, Fundamentals of experiment work in animal husbandry, 304 (1976)

6. Sh.A. Imangulov, Methodology for conducting scientific and industrial research on feeding poultry, 35 (2000)

7. E.V. Eidrigevich, V.V. Raevskaya, Interior of farm animals, 255 (1978)

8. A.A. Bakharev, O.M. Sheveleva, M.A. Chasovshchikova, S.S. Aleksandrova, S.F. Sukhanova, A.G. Koshchaev, IOP Conference Series: Earth and Environmental Science, 012097 (2021)

9. O.M. Sheveleva, A.A. Bakharev, L.A. Lysenko, M.A. Chasovshchikova, E3S Web of Conferences, FARBA 2021 (2021)

10. K.A. Sidorova, O.A. Dragic, S.A. Pashayan, M.V. Kalashnikova, S.V. Kozlova, Physiological properties of blood and lymph of animals, 64 (2004)

11. G.S. Azaubaeva, Blood count in animals and poultry, 168 (2004)

12. D.R. Amirov, Clinical and instrumental research methods and laboratory diagnostics for non-infectious birds' pathology, 28 (2015)

13. General and special methods for the blood study of poultry of industrial crosses, 85 (2009)

14. O.M. Sheveleva, A.A. Bakharev, S.F. Sukhanova, IOP Conference Series: Earth and Environmental Science, 012023 (2019) 